\title{
sobre algo bem triste
}

\section{Luisa Bianchetti}

manifesto-me em favor de algo bem triste.

um espectro ronda a vida - o espectro da tristeza.

todas as potências unem-se em santa aliança para aplacá-la:

a alegria e a felicidade, as religiões e o trabalho,

os mais livres e as famílias brasileiras.

é verdade: dizem que a tristeza nos trucidará. vamos prová-los errados, como sempre

os velhos inimigos, felizes, frígidos míopes, tombarão um por um enquanto celebramos com melancolia. a inexplicável força invisível, ela, é ela.

tristeza protetora, bom dia, intrépida esposa. carregados ao fundo do poço... o horror, o horror e a queda. a náusea.

mas eis que a tristeza estraçalha o silêncio, volta e volta com juras e luz! coração cansado todos temos, e brilhos diferentes e chances raras pela frente. leve-nos até o fim, tristeza criatura. vamos fechar os olhos. 